Article

\title{
Anatomy of the Windmill Palm (Trachycarpus fortunei) and Its Application Potential
}

\author{
Jiawei Zhu ${ }^{1}$, Jing $\mathrm{Li}^{1,2}$, Chuangui Wang ${ }^{3}$ and Hankun Wang ${ }^{1, *}$ \\ 1 Department of Biomaterials, International Center for Bamboo and Rattan, State Forestry Administration \\ and Beijing Co-Built Key Lab for Bamboo and Rattan Science \& Technology, Beijing 100102, China; \\ zhujw@icbr.ac.cn (J.Z.); jingtuo_8585@126.com (J.L.) \\ 2 Key Lab of Wood Science and Technology of National Forestry and Grassland Administration, \\ Research Institute of Wood Industry, Chinese Academy of Forestry, Beijing 100102, China \\ 3 School of Forestry \& Landscape Architecture, Anhui Agricultural University, Hefei 230036, China; \\ nj230036@163.com \\ * Correspondence: wanghankun@icbr.ac.cn
}

Received: 13 November 2019; Accepted: 9 December 2019; Published: 10 December 2019

\begin{abstract}
The windmill palm (Trachycarpus fortunei (Hook.) H. Wendl.) is widely distributed and is an important potential source of lignocellulosic materials. The lack of knowledge on the anatomy of the windmill palm has led to its inefficient use. In this paper, the diversity in vascular bundle types, shape, surface, and tissue proportions in the leaf sheaths and stems were studied with digital microscopy and scanning electron microscope (SEM). Simultaneously, fiber dimensions, fiber surfaces, cell wall ultrastructure, and micromechanics were studied with atomic force microscopy (AFM) and a nanoindenter. There is diversity among vascular bundles in stems and leaf sheaths. All vascular bundles in the stems are type B (circular vascular tissue (VT) at the edge of the fibrous sheath (FS)) while the leaf sheath vascular bundles mostly belong to type C (aliform (VT) at the center of the (FS), with the wings of the (VT) extending to the edge of the vascular bundles). In addition, variation among the vascular bundle area and tissue proportion in the radial direction of the stems and different layers of the leaf sheaths is also significant. Microscopically, the fibers in the stem are much wider and longer than that in the leaf sheath. The secondary walls of stem fibers are triple layered while those in the leaf sheath are double layered. The indentation modulus and hardness of the cell wall of leaf sheath fibers are higher than that of the stem. An independent sample $t$-test also showed a significant difference between stems and leaf sheaths. All this indicates that windmill palm stems and leaf sheaths are two different materials and have different application prospects.
\end{abstract}

Keywords: Trachycarpus fortunei; vascular bundles; fibers; anatomy; leaf sheath; palm stem; nanoindentation

\section{Introduction}

The growing environmental crisis has driven efforts for the development of new ecologically sustainable materials. Wood has many useful properties, but wood shortage is a global problem today. The wood shortage has contributed to the rising price of construction materials that has indirectly led to rising housing prices in China. The development of composite materials, especially biomass composites, is an important means to solve this dilemma due to their production being environmentally sustainable and cheap. Recently, materials, such as straw [1], wood processing residues, and grass, have become biomass fillers in composite materials, but they each have their own shortcomings, including impurities, poor adhesion, and so on. The development of a homogenous, mass-produced biomass material would be a significant technological advance. 
The palm Trachycarpus fortunei (Hook.) H. Wendl. belongs to a genus with nine species, and is named a windmill palm due to its wind resistance [2,3]. The windmill palm stem is covered with black-brown leaf sheaths that can be harvested for fiber products once a year [4]. Although palms are mostly found in the tropics, the windmill palm is also distributed in northern China due to its frost resistance. It also possesses great salt and alkali tolerance. The palm stem decays quickly if not promptly treated after harvest because of its high moisture content. The leaf sheaths, on the other hand, are easy to obtain and have satisfactory properties for the production of cordage, ropes, and other fiber products [5], and have become the subject of applied research in recent years.

The leaf sheath of the windmill palm has three advantageous characteristics when compared with more common biomaterials, such as wood or bamboo. According to Zhai [6], the leaf sheath fiber microfibril angle (MFA) of the first layer of secondary wall (S1) is $127.0^{\circ}$ and those of the second layer of secondary wall (S2) is $43.7^{\circ}$, which is much larger than in common biomass materials. Some researchers believe that the high MFA of fibers is related to their high flexibility and leads to long-term plastic deformation when under pressure [5]. Secondly, the chemical composition of windmill palm leaf sheath fibers is $44.07 \%$ lignin, $28.2 \%$ cellulose, $20.6 \%$ hemicellulose, and $3.8 \%$ wax [7]. This high lignin content is responsible for many of the leaf sheath's important mechanical properties, such as durability, elasticity, and high flexibility [8]. Thirdly, there is a high number of silica bodies on the surface of the leaf sheaths [9]. The presence of silica cells or stegmata [10] are responsible for many useful properties, such as porosity, anti-corrosion, and anti-pathogenic fungi [7]. On the other hand, silica bodies also cause many kinds of problems, such as poor adhesion when manufacturing composite materials, and impurities that are difficult to remove when making pulp and paper [11]. Therefore, much recent research has focused on exploring ways to remove silica bodies from the leaf sheath surface. The most commonly used and effective way to remove silica bodies is mercerization using alkali treatment $[9,12,13]$. Chen [9] showed that alkali treatment can not only smooth the surface but also improve the sheath's mechanical properties. Steam explosion is also an effective method, with the advantage of a shorter operating time and lower pollution compared with alkali treatment [11].

Leaf sheaths were used for making traditional clothes and working tools for thousands of years $[14,15]$. The application was relatively primitive, and much material was wasted. In modern materials, leaf sheaths have many applications. When used as biomass composites [16-19], they have better adhesive properties than ordinary materials. Windmill palm fiber-based activated carbon materials, such as those made by Li et al. [20], show a remarkable adsorption capacity, and the authors suggested that this accounts for their great potential value. Oushabi [21] demonstrated experimentally that palm composite materials have good properties compared with other insulating materials in a high temperature environment. Zhang [22] and Chen [23] suggested that windmill palm fibers are suitable for use in textiles because of their basically porous structure and toughness. Leaf sheath fibers also have applications in microscopic fields. The authors of [24] showed that palm fiber is a valuable source for the production of cellulose nanocrystals (CNCs) and the resulting performance is no weaker than that of wood or bamboo. Caramyshev [25] extracted peroxide that showed excellent stability in high temperatures, and highly concentrated proportions of guanidine from cell walls and conducting bundles of windmill palm. Although windmill palms have been applied extensively in many fields, there are still three aspects of its use that need attention. Firstly, much attention has been paid to palm leaf research, but few studies have been done on palm stems. Secondly, studies on windmill palms remain mostly at the scale of vascular bundles, but few studies have been done at the fiber scale. Thirdly, not enough attention has been paid to the anatomical variation within windmill palms. For example, although the leaf sheaths of palms can be divided into three layers, and each layer has a very different structure and resultant properties, previous research tends to treat the leaf sheath as one unvarying object.

With this in mind, we studied the anatomical structure and variation of windmill palm stems and leaf sheaths using digital microscopy and scanning electron microscopy (SEM). At the same time, we also used polarized light microscopy (PLM) and atomic force microscopy (AFM) to study 
differences in the fiber dimension, fiber surface, and fiber cell wall between stems and leaf sheaths. In order to further explore the differences between the palm leaf sheath and stem fibers, nanoindentation was applied. The objective of the study was not only to increase anatomical data on the windmill palm but also to provide a foundation for more scientific and efficient use of windmill palm that can alleviate the present shortage of lignocellulosic materials.

\section{Materials and Methods}

\subsection{Materials}

Three windmill palms (Trachycarpus fortunei), approximately $5 \mathrm{~m}$ tall and with a diameter at breast height (DBH) of approximately $15 \mathrm{~cm}$, were obtained from the Sentai Company in Anhui Province, China. Stems and leaf sheath meshes were separated manually. In order to eliminate the variation of height, samples were taken at $0.5,1,2,3$, and $4 \mathrm{~m}$ of the palm, respectively (Figure $1 \mathrm{~A}$ ). The average value was used in the calculation. The samples were rinsed in warm water to gently remove dust and residual soil from their surface, and then dried for $24 \mathrm{~h}$ at $60{ }^{\circ} \mathrm{C}$, and stored at $25^{\circ} \mathrm{C}$ and $65 \%$ humidity.

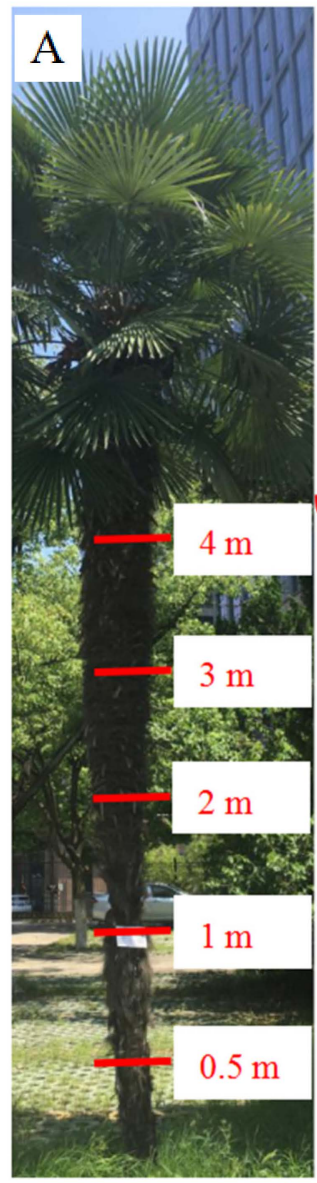

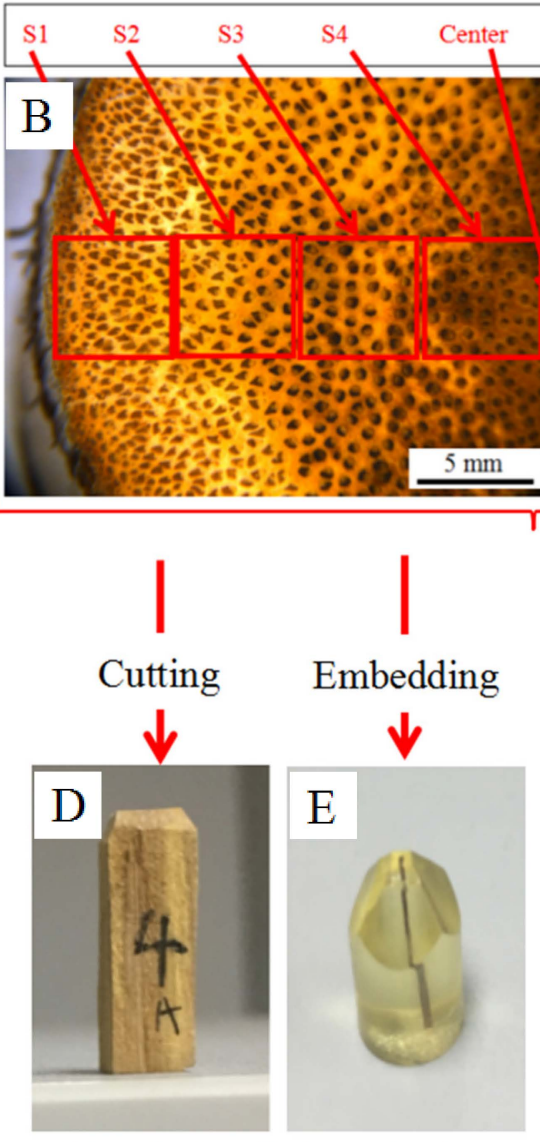

Vascular bundle investigation
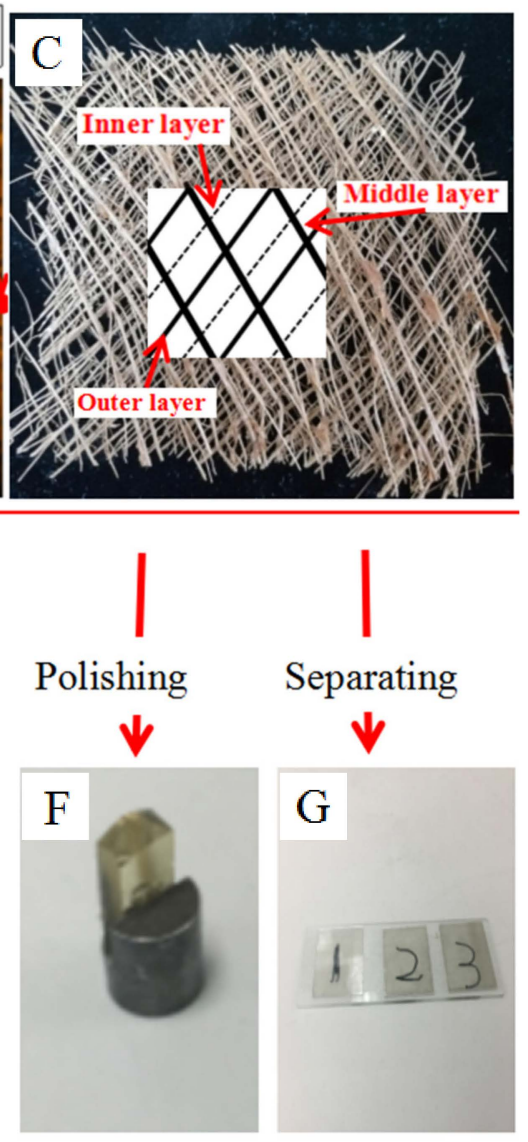

Fiber investigation

Figure 1. Samples preparation of Trachycarpus fortunei stems and leaf sheaths for vascular bundle and fiber investigation. (A): Trachycarpus fortunei, (B): Stem, (C): Leaf sheath, (D): Stem sample for vascular bundle investigation, (E): Leaf sheath sample for vascular bundle investigation, (F): Fiber sample for atomic force microscopy (AFM) and nanoindentation, (G): Fiber sample for AFM and polarized light microscopy (PLM).

\subsection{Morphological Observations and Measurement of Vascular Bundles}

The stems were divided into four equal parts of 5 (radial) $\times 5$ (tangential) $\times 10$ (longitudinal) $\mathrm{mm}^{3}$ in dimension (Figure $1 \mathrm{~B}$ ). These pieces were labelled as S1, S2, S3, and S4, depending on their 
distance from the center, with S1 being the piece closest to the edge and S4 being taken from the center. The pieces were softened for $4 \mathrm{~h}$ at $60{ }^{\circ} \mathrm{C}$ in water, and then smooth transverse sections on the top of the pieces were cut by sharp blades for vascular bundle investigation (Figure 1D). The sheath meshes were split into an inner sheath mat layer, middle layer, and outer layer, and vascular bundles were extracted from each layer (Figure 1C). The single leaf sheath vascular bundle needed embedding before the transverse sections' investigation due to its small dimension (Figure 1E). Firstly, the leaf sheath was dehydrated with alcohol and spurr resin, and then the vascular bundles were inserted vertically into the embedding tube with spurr resin, followed by vacuum drying for $8 \mathrm{~h}$ at $70{ }^{\circ} \mathrm{C}$. After resin curing, the pyramid top was cut at the top of the samples (Figure 1E). All images were collected by a digital microscope (XTS20G, Fukai LTD. Qindao, China) under the same magnification of $\times 50$. Quantitative characteristics, including vascular bundle type, proportion of tissues, and shape, were determined by means of photographs that were previously obtained from Graph processing software (Image-proplus 6.0, Media Cybernetics, Rockville, MD, USA). Data processing software (Origin 8.5, Originlab Co, Northampton, MA, USA) was used to summarize and analyze these features and obtain sample means and standard deviations. In total, 60 pieces of stem and 90 leaf sheaths were studied.

In addition, a scanning electron microscope (FEI-ESEM; XL-30; FEI, Hillsboro, OR, USA) with an acceleproportion voltage of $7 \mathrm{kV}$ was used to observe the structure of the vascular bundle in more detail. The vascular bundles in the stems were separated manually with a sharp razor blade so as to make the vascular bundles lateral surface visible. The vascular bundles of stems and leaf sheaths were glued to the electron microscope holder with transverse and lateral placement, so as to expose the transverse and longitudinal surface. All the samples were gold plated in vacuum to provide enough conductivity.

\subsection{Measurement of Fiber Dimensions and Cell Walls}

Measurements of fibers were taken from samples of both stems and leaf sheaths. Samples were macerated in a solution of hydrogen peroxide and acetic acid (1:1 proportion) at $60{ }^{\circ} \mathrm{C}$ for $12 \mathrm{~h}$ [26]. Samples were then cleaned with distilled water until the solution was neutral and completely whitened, and the fibers were separated by a gentle shake. The fibers were added onto a mica sheet (Figure 1G). A polarized light microscope (PLM; 60XC; Horke Co, Shanghai, China) and Image-proplus 6.0 software were used to collect and measure the dimensions of 50 fibers in each stem and leaf sheath sample. An atomic force microscope (AFM; Dimension ICON; Bruker Co, Billerica, MA, USA) was used to observe the fiber surface and cell wall. The sample used for observation of the fiber surface used mica chips as a substrate, and was freeze-dried to prevent surface damage from rapid evaporation. The samples used for observations of the fiber cell wall were also used for observation of the transverse section of the vascular bundle, after exposing the transverse surface with a diamond knife to allow the AFM to function (Figure $1 F$ ). The prepared samples were observed in the AFM's tapping mode. The edge length of the scanned image gradually decreased from $20 \mu \mathrm{m}$ to $500 \mathrm{~nm}$. The scanned images were analyzed by AFM-related software (NanoScope Analysis 4.0, Bruker Co, Billerica, MA, USA).

\subsection{Nanoindentation of the Two Kinds of Fiber}

Nanoindentation was developed from conventional impression hardness testing, but it gives rise to a much higher resolution both in load and depth measurement. The samples used for AFM were used again for indenting by a Triboindenter (Hysitron, Minneapolis, MN, USA) (Figure 1F). The loading force curve was selected as 5-2-2 s, $250 \mu \mathrm{N}$, and the loading mode was chosen to be constant loading. There was probe scanning before indenting, which revealed the topographic surface of the sample cross-section, and several points were located and marked on each topographic image for indentation. After nanoindentation, rescanning was performed to verify the indentation position; 20 effective indentation points were used to calculate the indentation modulus and hardness of fibers. 


\subsection{Statistically Significant Differences Analysis}

Independent-sample $t$-test was applied here via statistical analysis software (SPSS 18.0, International Business Machine, Almonk, NY, USA) to explore significant differences between windmill palm stems and leaf sheaths more scientifically. The cross-sectional area of the vascular bundle, fiber dimension, fibril diameter, and the fiber cell wall mechanical properties of stems and leaf sheaths were analyzed. It is generally believed that the difference is significant if the significance level is less than 0.05 .

\section{Results and Discussion}

\subsection{Anatomical Structure of Vascular Bundles}

Similar to vascular bundles in the stems, a single leaf sheath of windmill palm is a single vascular bundle composed of fibers and many other types of cells that constitute the fibrous sheath, phloem, xylem vessels, and parenchyma. Xylem and phloem tissues are clearly distinguishable in the vascular bundles of stems and leaf sheaths (Figure 2B-E,G-I). It is important to note that there are many wide metaxylem vessels in windmill palm vascular bundles, unlike the two found in bamboo vascular bundles, and three reported in oil palm [27]. For convenience, phloem, vessels, and parenchyma in vascular bundles are defined as asvascular tissue (VT), and the xylem is surrounded by a fibrous sheath (FS). Vascular bundles of 18 species of palm leaf sheaths were studied by Zhai et al. [8,28], who suggested that vascular bundles could be roughly divided into three categories based on the position of VT and FS in the vascular bundle:

- Type A: Circular VT is located in the center of FS (Figure 3B);

- Type B: Circular VT at the edge of FS (Figure 3A); and

- Type C: Aliform VT at the center of the FS, with the wings of the VT extending to the edge of the vascular bundles (Figure 3B).

In the stem, all vascular bundles are type B, and the VTs are almost all circular, but the shape of the FS varies greatly (Figure 2B-E). It is difficult to distinguish the type of vascular bundle in the inner leaf sheath due to the small size of the VT (Figure 2G); it may belong to type A. The middle and outer leaf sheath have type $\mathrm{C}$ vascular bundles (Figure $2 \mathrm{H}, \mathrm{I}$ ). 

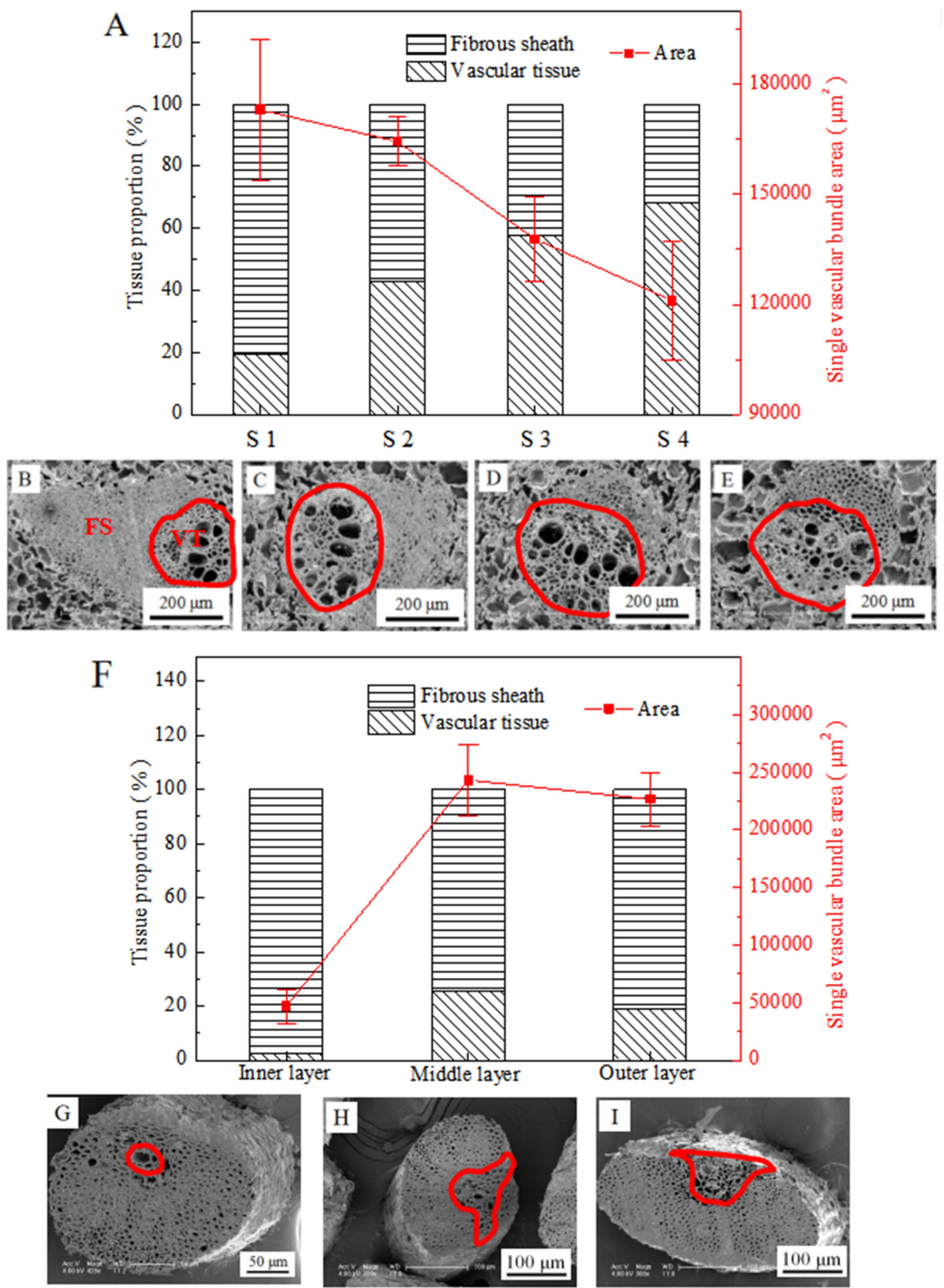

Figure 2. Tissue proportion and single vascular bundle area in (A): stem, (F): Leaf sheath; and SEM micrograph of vascular bundle in (B-E): S1 to S4, (G-I): Inner leaf sheath, middle leaf sheath, outer leaf sheath. 

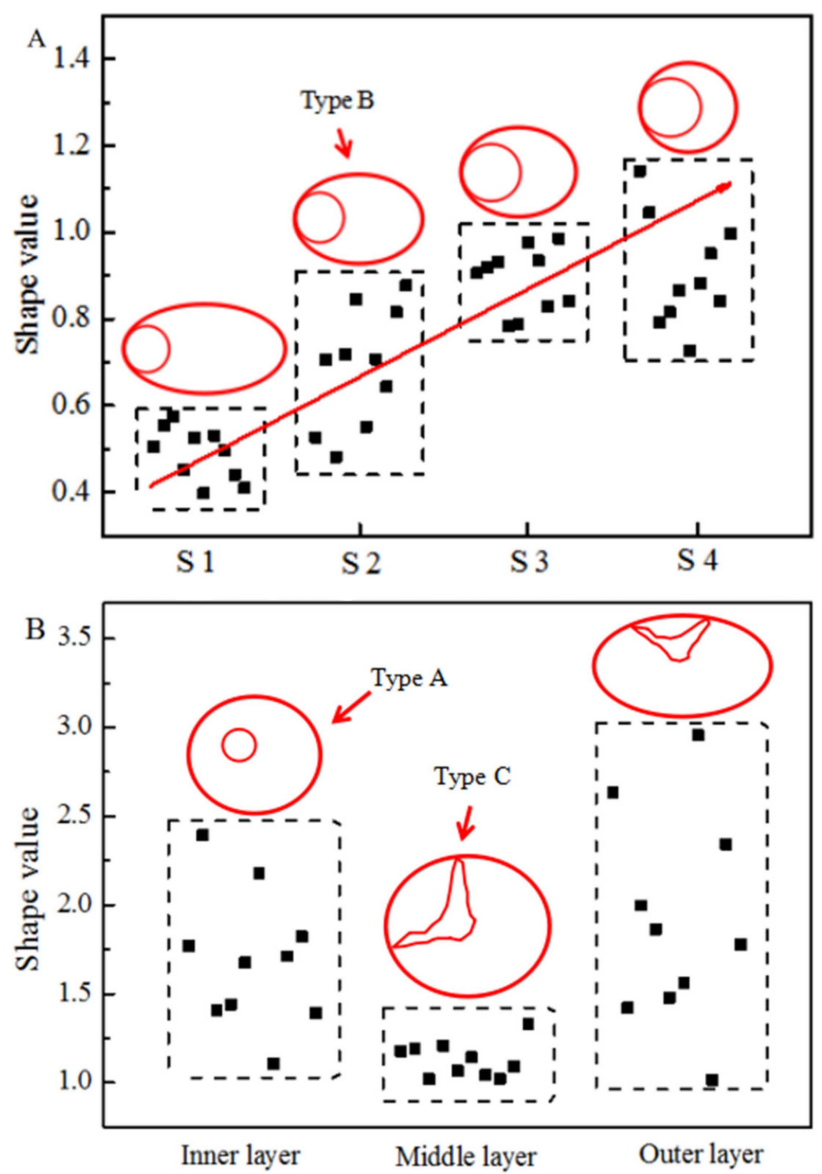

Figure 3. Shape value of vascular bundle and the vascular bundle type $[8,28]$ in $(\mathbf{A})$ : Stem, (B): Leaf sheath.

\subsection{Shape of Vascular Bundles}

Length was defined as the maximum distance to pass through the center of the VT in the vascular bundle. Width was defined as the maximum distance perpendicular to the length. We quantified the variable "shape value" as follows:

$$
\text { Shape value }=(\text { Width } / \text { length }) .
$$

The shape of the vascular bundles is closer to round when the shape value is closer to 1 . As shown in Figure 3A, the shape value of the vascular bundles in the S1 samples is 0.4 to 0.6 while the shape value of vascular bundles in the $S 4$ samples is closer to 1 . The shape value of vascular bundles in the stem increases from the edge to the center, which indicates that the vascular bundles vary regularly in the radial direction. In particular, the closer the vascular bundle is to the stem center, the rounder the vascular bundle. This pattern is similar to the radial variation of bamboo vascular bundles [29].

The shape values for leaf sheaths are shown in Figure 3B; they are almost all greater than 1. The shape values of the middle leaf sheath are close to 1 and the range is approximately 0.3 . This means the vascular bundles are mostly round. The range of shape values for the inner leaf sheath is approximately 1.5 while the range of the outer leaf sheath is approximately 2.0. The shape of outer leaf sheath is changeable [30].

\subsection{Tissue Proportion of Vascular Bundles}

Vascular bundles in the windmill palm vary not only in shape but also in tissue proportion and area with a single vascular bundle. As shown in Figure 2A, the area of vascular bundles in $\mathrm{S} 1$ is larger 
$\left(0.17 \pm 0.02 \mathrm{~mm}^{2}\right)$ than that in $\mathrm{S} 4\left(0.12 \pm 0.02 \mathrm{~mm}^{2}\right)$. Furthermore, from the edge to the center in a single vascular bundle, the area and the proportion of FS gradually decreases while the proportion of VT increases. The area and the proportions of FS and VT in the three layers of the leaf sheath are shown in Figure 2F. The area of vascular bundles in the inner leaf sheath layer is the smallest, but the tissue proportion of FS is the highest here. It is almost completely composed of fibers, the exact opposite of vascular bundles in the middle leaf sheath, which has a high proportion of VT.

The tissue proportions of vascular bundles are closely related to the function. The main function of the FS in the vascular bundle is physical support while the main function of the VT is the transport of water, nutrients, and inorganic salts [3]. It can be inferred that the vascular bundles at the edge of the stem play an important role in enhancing certain physical properties while the vascular bundles in the central part of the stem are mainly responsible for transportation due to their high proportion of VT [31].

\subsection{Lateral Surface of the Vascular Bundles}

SEM images show that the vascular bundles of the windmill palm have numerous stigmata and silica bodies (Figure 4C,D) on their lateral surface. Like Chen et al. [32] and Luo et al. [11], we observed silica bodies in fibers that were abundant in the vascular bundles of windmill palm leaf sheath (Figure 4A). The difference is that the silica bodies in fibers were also found in the bundle sheaths of stem vascular bundles, albeit less abundant than in the leaf sheath (Figure 4B). Furthermore, the presence of stigmata increases the surface area of vascular bundles, which is very helpful in enhancing the adhesiveness between the composites when palm vascular bundles are used as a reinforcement material. The longitudinal section of vascular bundles (Figure 4E) showed that windmill palm fibers may have a large MFA, which is consistent with Zhai's suggestion [6].
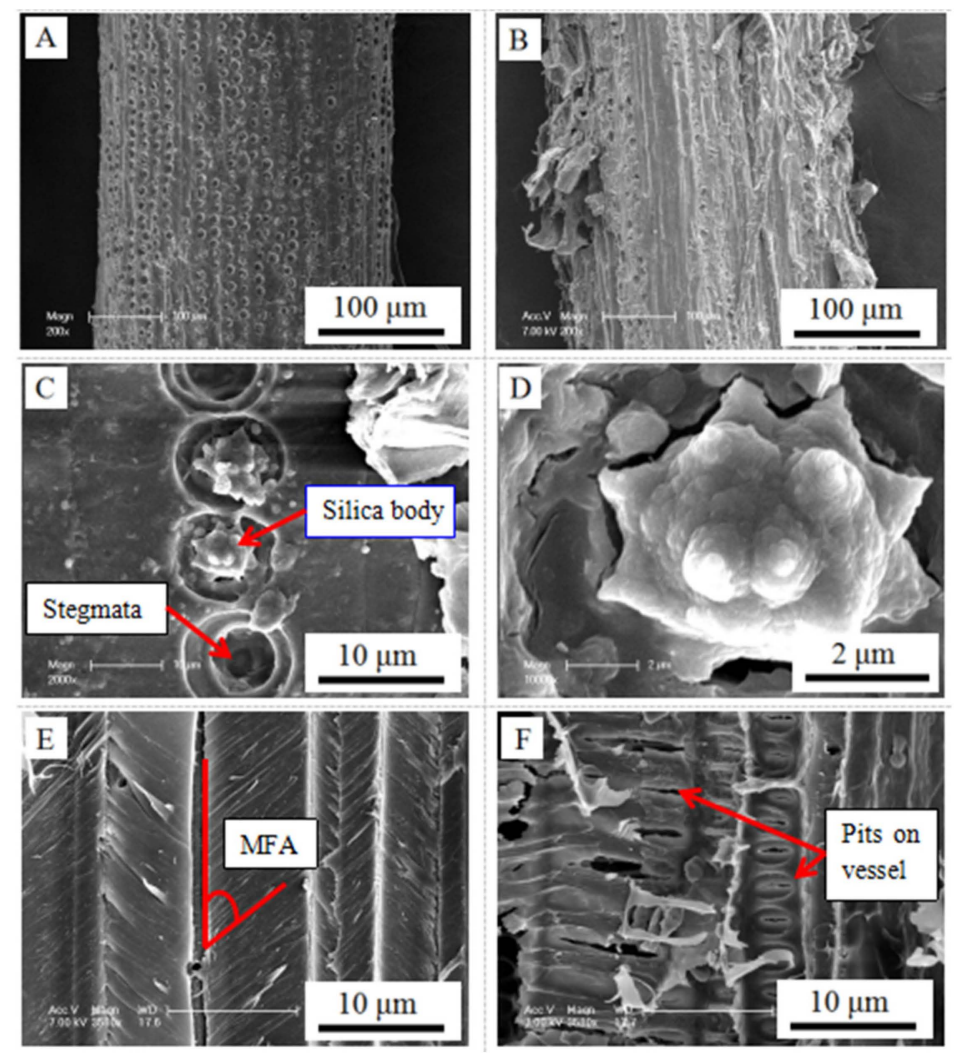

Figure 4. SEM micrograph of vascular bundle surface in (A): stem, (B): Leaf sheath; (C): Silica body and stigmata, (D): Silica body; (E): Fibers in the longitudinal section of vascular bundles; (F): Vessels in the longitudinal section of vascular bundles. 


\subsection{Dimensions of Fibers}

Fiber dimension is a particularly important characteristic as it relates to properties desirable for applications (e.g., strength properties) [33]. A series of statistical fiber dimensional data were obtained using a polarizing microscope processed by Image-proplus 6.0 software (Table 1). The data show that the fiber length in leaf sheaths range between 450 and $950 \mu \mathrm{m}$, of which $52 \%$ are distributed between 600 and $800 \mu \mathrm{m}$, which is consistent with the literature [32], and the fiber width in leaf sheaths ranges between 5 and $20 \mu \mathrm{m}$, of which $84 \%$ are distributed between 10 and $20 \mu \mathrm{m}$ (Figure 5). Nevertheless, the fiber length in the stem is mainly distributed between 800 and $1700 \mu \mathrm{m}$, of which $42 \%$ are distributed between 1000 and $1200 \mu \mathrm{m}$, and the fiber width in the stem ranges between 25 and $65 \mu \mathrm{m}$, of which $72 \%$ are distributed between 30 and $50 \mu \mathrm{m}$ (Figure 5). The fibers in the stem are longer and much wider than that in the leaf sheath.

Table 1. Fiber dimension in stem and leaf sheath (SD: Standard deviation).

\begin{tabular}{ccccccc}
\hline & Length $(\mu \mathrm{m})$ & SD & Width $(\mu \mathrm{m})$ & SD & Length/Width & SD \\
\hline Fiber in stem & 1260.63 & 279.59 & 42.00 & 10.11 & 32.08 & 12.85 \\
Fiber in leaf sheath & 710.89 & 125.61 & 12.77 & 2.67 & 58.08 & 16.89 \\
\hline
\end{tabular}

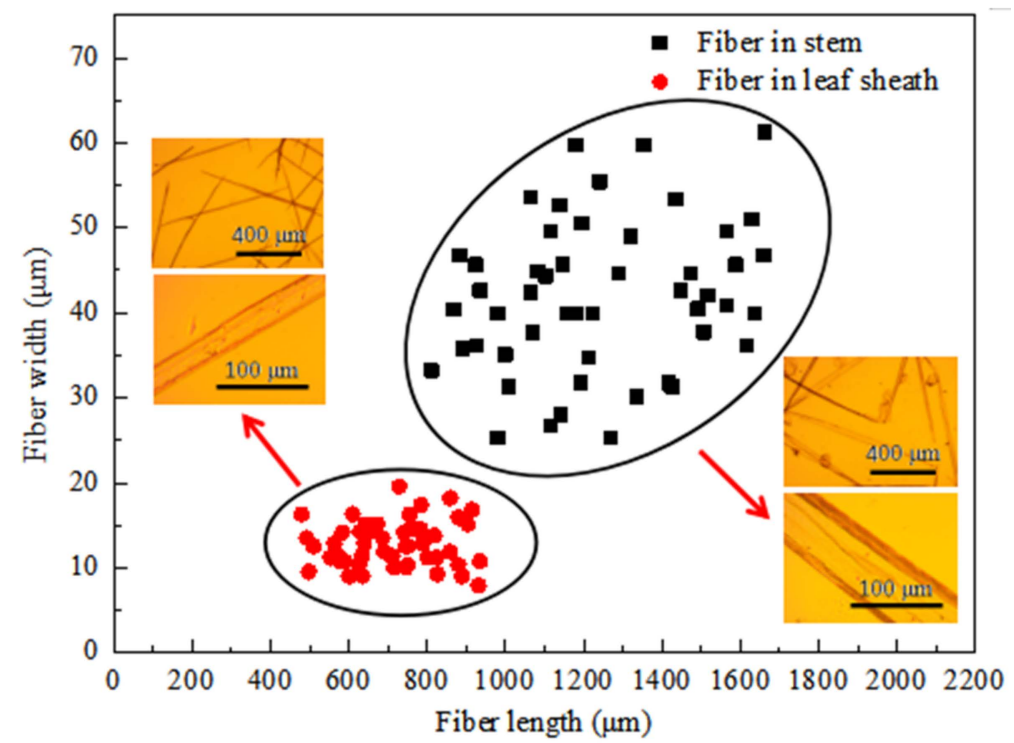

Figure 5. Distribution of the fiber dimension in windmill palm stem and leaf sheath.

\subsection{Fiber Outer Surface Microstructure}

Atomic force microscopy provides a unique way to study the fiber microstructure [34]. The outer surface microstructure of windmill palm fiber can be seen clearly in Figure 6. There are more exposed fibrils on the surface of the fibers, and obvious differences in the dimension and orientation of the fibrils between the fibers in the stems and leaf sheaths. Most of the fibrils in the stem fiber surface are configured in a readily apparent orientation (Figure 6A) while the fibrils in the leaf sheath are arranged in a disorderly way (Figure 6B). The diameter of fibrils in the stem fibers' surface ranges from 18 to $24 \mathrm{~nm}$ (average $=20.53 \mathrm{~nm}$ ), which is similar to wheat straw fiber $(20 \mathrm{~nm})$ [35], while, the diameter of fibrils in the leaf sheath fibers' surface ranges from 38 to $44 \mathrm{~nm}$ (average $=41.32 \mathrm{~nm}$ ) (Figure 6C). 


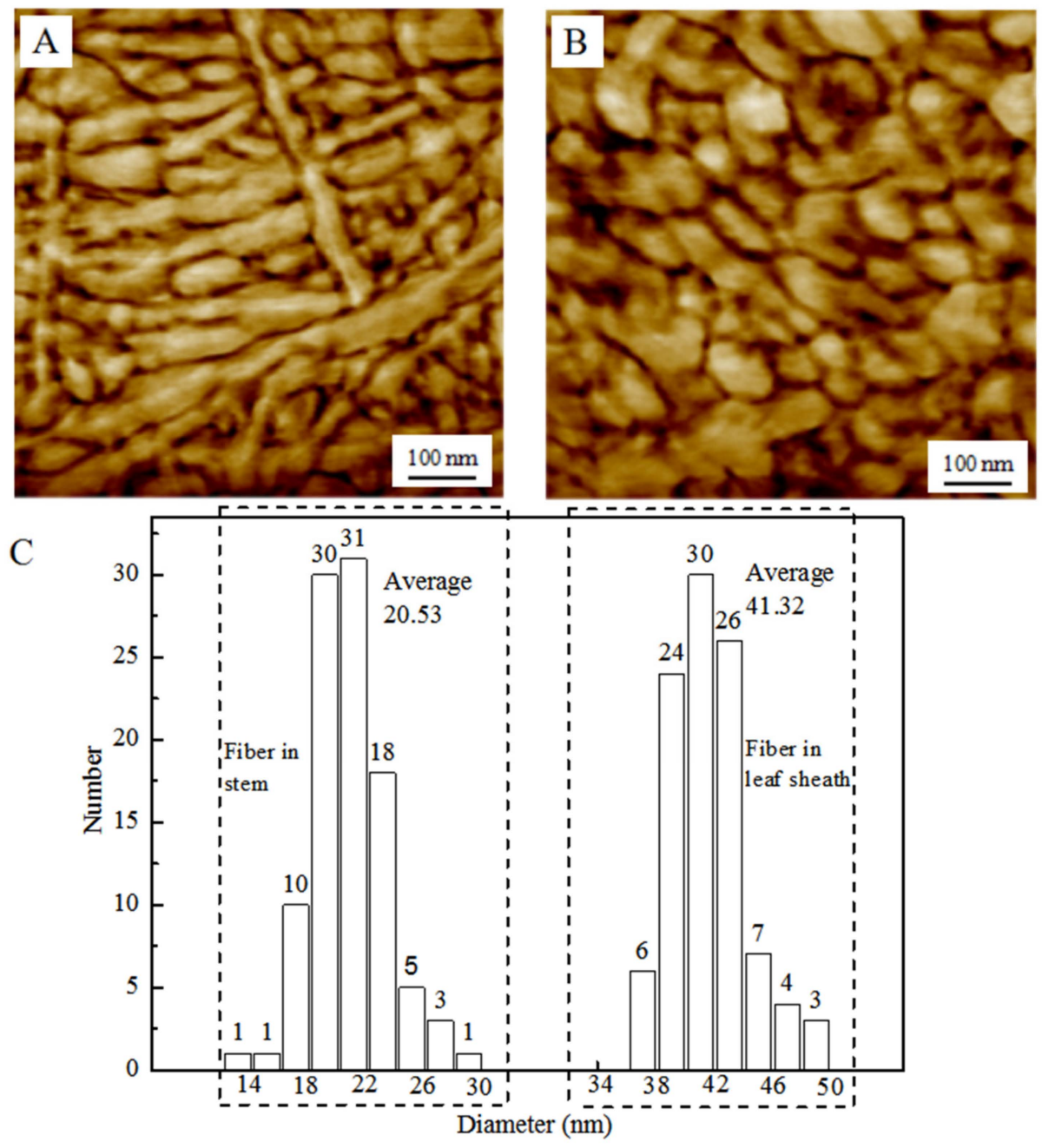

Figure 6. AFM micrograph of fibrils on the surface of fibers in (A): Stem, (B): Leaf sheath; (C): Dimensional distribution of fibrils.

\subsection{Fiber Cell Wall Ultrastructure}

From an application point of view, the wall thickness and number of layers are two important cell wall characteristics. The cell wall ultrastructure in the leaf sheath is shown in Figure 7. We can see that the secondary cell wall of the leaf sheath consists of two layers (Figure 7D), which is consistent with reports in the literature on the fiber cell wall of various kinds of palm leaf sheaths [6]. The cell wall is between 2.01 and $2.42 \mu \mathrm{m}$ thick, extremely close to the numbers reported in a study of windmill palm leaf sheath fibers by Chen [32]. The fibers in the stem seem to have their own unique characteristics, which distinguish them from leaf sheath fibers. Figure 7A shows the relationship between the fiber wall thickness and the distribution of fibers in a single vascular bundle. When the fiber is closer to the VT, the cell wall is thicker. The number of the fiber secondary cell wall layers (excluding the primary wall) also varies between the stem and leaf sheath. Both of the thick-walled (approximately $3.75 \mu \mathrm{m}$ ) fiber cells near the VT and the thin-walled (approximately $1.75 \mu \mathrm{m}$ ) fiber located away from the VT had three layers (Figure 7B,C). 

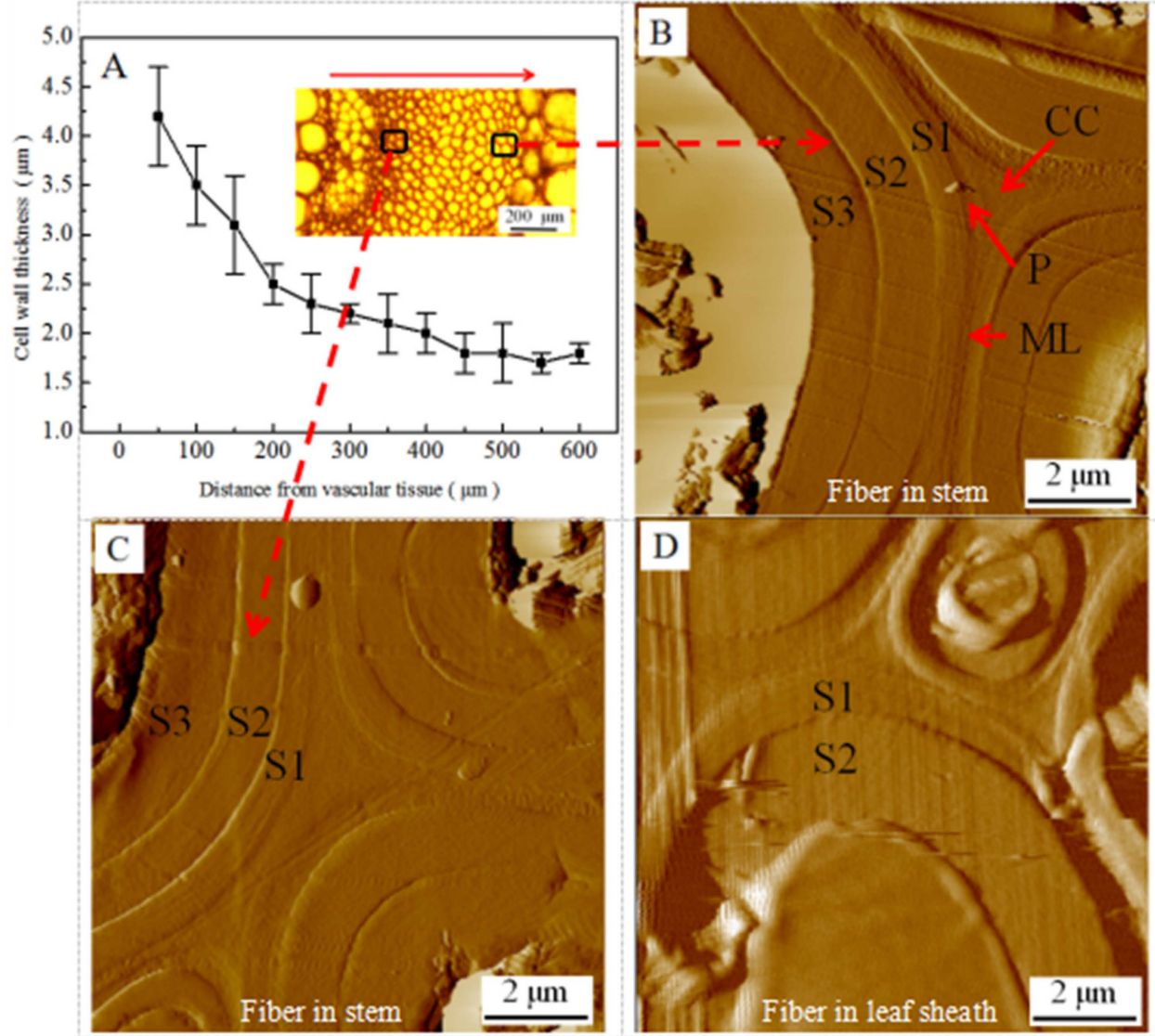

Figure 7. (A): Correlation between the fiber thickness and the distance to the vascular tissue in a single stem vascular bundle; and the AFM micrograph of (B): Thin-walled fiber in stem, (C): Thick-walled fiber of stem, (D): Fiber in leaf sheath. (P-Primary wall; CC—Cell corner; ML—Middle lamella; S1—First layer of secondary wall; S2-Second layer of secondary wall; S3-Third layer of secondary wall).

\subsection{Mechanical Properties of Fiber Cell Wall}

In order to further explore the difference between fibers with three layers of secondary walls in the stem and fibers with two layers of secondary walls in the leaf sheath, nanoindentation tests were performed. Nanoindentation has long been used in the field of wood science for estimating the mechanical properties of the secondary wall and the cell corner middle lamella of spruce tracheids [36]. Until now, it has a more comprehensive function, and is also a powerful technique to directly characterize the mechanical properties of the cell wall at the micrometer or even nanometer scale.

The results show that the indentation modulus of the fiber walls in leaf sheaths (9.68 GPa) is only $15.51 \%$ higher than that in stem fibers (8.38 GPa), but the hardness of fiber in the leaf sheath ( $420.81 \mathrm{MPa}$ ) is $29.49 \%$ higher than that of fiber in the stem (324.97 MPa) (Figure 8). The T-test also showed a significant difference between the stem and leaf sheath (Table 2). This indicates that the fibers in the stem and leaf sheath are different in structure, and in cell wall mechanical properties, especially for hardness. To further understand the mechanical characteristics of the windmill palm fibers, the values were compared to those for poplar (Angiosperms dicotyledons) from $\mathrm{Wu}$ et al. [37], spruce (gymnosperms) from Gindl et al. [36], bamboo (Angiosperms monocotyledons) from Yu et al. [38], and rice straw (Angiosperms monocotyledons) from Wu et al. [39], as shown in Table 3. The results showed that the indentation modulus of palm fibers was significantly lower than those of other fibers, which may be caused by its larger fiber microfibril angle (MFA) [6]. Noteworthily, the hardness of fiber in the stem (which is close to bamboo and spruce) is lower than that of fiber in the leaf sheath (which is close to poplar and rice straw). 


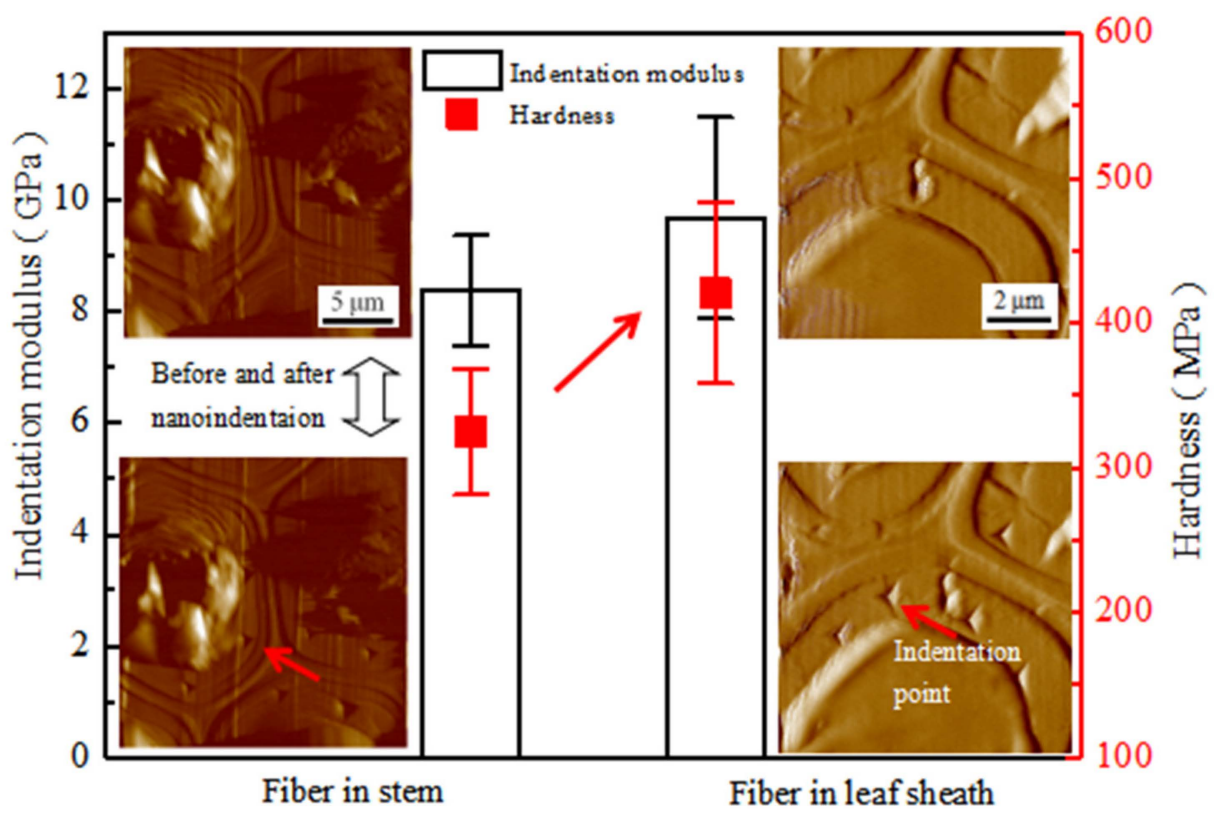

Figure 8. Hardness and indentation modulus of the secondary cell wall of windmill palm fibers.

Table 2. Difference analysis based on T-test between the stem and leaf sheath.

\begin{tabular}{cc}
\hline \multicolumn{2}{c}{ Independent-Sample t-Test } \\
\hline Sample & Significance (sig.) \\
\hline Cross sectional area of vascular bundle (Factor 1) & 0.0000 \\
\hline Fiber length (Factor 2) & 0.0000 \\
\hline Fiber diameter (Factor 3) & 0.0000 \\
\hline Fibril diameter (Factor 4) & 0.0000 \\
\hline Cell wall indentation modulus (Factor 5) & 0.0394 \\
\hline Cell wall hardness (Factor 6) & 0.0002 \\
\hline Stem and leaf sheath (Total analysis) & Significant difference \\
\hline Note: Difference is significant when significance less than 0.0500.
\end{tabular}

Table 3. Comparison of fiber mechanical properties of hardwoods, softwoods, bamboo, straw, and palm measured by nanoindentation.

\begin{tabular}{cccccc}
\hline & Latin Name & $\begin{array}{c}\text { Indentation } \\
\text { Modulus (GPa) }\end{array}$ & SD & $\begin{array}{c}\text { Hardness } \\
\text { (MPa) }\end{array}$ & SD \\
\hline Poplar & Populus & 16.90 & 1.88 & 490.00 & 46.70 \\
Spruce & Picea abies & 17.40 & 1.04 & 380.00 & 26.60 \\
Bamboo & Phyllostachys pubescens & 16.00 & 3.15 & 359.90 & 104.30 \\
Rice straw & Oryza sativa & 19.40 & 1.48 & 500.00 & 66.00 \\
Fiber in stem & Trachycarpus fortunei & 8.38 & 0.99 & 324.97 & 43.33 \\
Fiber in leaf sheath & Trachycarpus fortunei & 9.68 & 1.81 & 420.81 & 62.45 \\
\hline
\end{tabular}

(Data of spruce from Gindl et al. [36]; Poplar from Wu et al. [37]; Bamboo from Yu et al. [38]; Rice straw from Wu et al. [39]).

\section{Conclusions}

In this study, the anatomy, microstructure, and micromechanics of windmill palm were investigated. The following conclusions were drawn: 
(1) Variation among vascular bundle area and tissue proportion in the radial direction of the stem and different layers of the leaf sheath are significant. The edge of the palm stem and inner leaf sheath may have relatively excellent mechanical properties due to the high proportion of FS.

(2) There is a large amount of silica bodies and stigmata on the lateral surface of the vascular bundle in windmill palm. The increase of the surface area caused by stigmata may contribute to its adhesion as a composite.

(3) Fibers in the stem are much wider and longer than that in the leaf sheath. From the perspective of a single dimension, stem fibers are more suitable for papermaking.

(4) The cell wall indentation modulus of windmill palm fiber is between 8.38 and $9.68 \mathrm{GPa}$. Noteworthy, the indentation modulus of windmill palm fiber is much smaller than that of wood (softwood and hardwood) or bamboo.

Author Contributions: Conceptualization, J.Z. and H.W.; writing-original draft preparation, J.Z.; investigation, J.Z. and J.L.; methodology, J.Z. and H.W.; funding acquisition, H.W. and C.W.

Funding: We would like to thank the Basic Scientific Research Funds of International Center for Bamboo and Rattan (1632018016) and 12th Five Years Key Technology R\&D Program (2015BAD04B03) for their financial support for this research.

Conflicts of Interest: The authors declare that they have no conflict of interest.

\section{References}

1. Ghaffar, S.H.; Fan, M. An aggregated understanding of physicochemical properties and surface functionalities of wheat straw node and internode. Ind. Crops Prod. 2017, 95, 207-215. [CrossRef]

2. Tomlinson, P.B. The structural biology of palms. In Quarterly Review of Biology; Oxford University Press: Oxford, UK, 1991. [CrossRef]

3. Eames, A.J.; Tomlinson, R.B. Anatomy of the monocotyledons, II Palmae. Bull. Torrey Bot. Club 1961, 89, 122. [CrossRef]

4. Zhai, S.; Pan, B.; Horikawa, Y.; Li, D.; Itoh, T.; Sugiyama, J. Structure and development of fibrovascular bundles from leaf sheath of windmill palm. J. Nanjing For. Univ. 2014, 38, 90-96. [CrossRef]

5. Zhai, S.; Pan, B.; Sugiyama, J.; Li, D.; Itoh, T. Tensile strength of windmill palm (Trachycarpus fortunei) fiber bundles and its structural implications. J. Mater. Sci. 2012, 47, 949-959. [CrossRef]

6. Zhai, S.; Sugiyama, J.; Itoh, T.; Pan, B.; Li, D. Cell wall characterization of windmill palm (Trachycarpus fortunei) fibers and its functional implications. Iawa J. 2013, 34, 20-33. [CrossRef]

7. Zhai, S. Structural, Chemical and Physical Properties of Palm Fiber; Nanjing Forest University: Nanjing, China, 2010.

8. Zhai, S. Anatomical and mechanical features of palm fibrovascular bundles. In Sustainable Humanosphere Bulletin of Research Institute for Sustainable Humanosphere Kyoto University; Kyoto University: Kyoto, Japan, 2014; Volume 10, pp. 22-23.

9. Chen, C.; Chen, G.; Li, X.; Guo, H.; Wang, G. The influence of chemical treatment on the mechanical properties of windmill palm fiber. Cellulose 2017, 24, 1611-1620. [CrossRef]

10. Schmitt, U.; Weiner, G.; Liese, W. The fine structure of the stegmata in calamus axillaris becc during maturation. Iawa J. 1995, 16, 61-88. [CrossRef]

11. Luo, H.; Zhang, H.; Yue, L.; Pizzi, A.; Lu, X. Effects of steam explosion on the characteristics of windmill palm fiber and its application to fiberboard. Eur. J. Wood Wood Prod. 2018, 76, 601-609. [CrossRef]

12. Al-Khanbashi, A.; Al-Kaabi, K.; Hammami, A. Date palm fibers as polymeric matrix reinforcement: Fiber characterization. Polym. Compos. 2010, 26, 486-497. [CrossRef]

13. Rashid, B.; Leman, Z.; Jawaid, M.; Ghazali, M.J.; Ishak, M.R. Physicochemical and thermal properties of lignocellulosic fiber from sugar palm fibers: Effect of treatment. Cellulose 2016, 23, 2905-2916. [CrossRef]

14. Essig, F.B.; Dong, Y.F. The many uses of Trachycarpus fortunei (Arecaceae) in China. Econ. Bot. 1987, 41, 411-417. [CrossRef]

15. Anders, B.; Manju, B.; John, D.; Henrik, B. SE Asian palms for agroforestry and home gardens. Forests 2015, 6, 4607-4616. [CrossRef] 
16. Bourmaud, A.; Dhakal, H.; Habrant, A.; Padovanic, J.; Siniscalcoa, D.; Ramaged, M.H.; Beaugrandce, J.; Darshil, U.S. Exploring the potential of waste leaf sheath date palm fibres for composite reinforcement through a structural and mechanical analysis. Compos. Part A Appl. Sci. Manuf. 2017, 103, 292-303. [CrossRef]

17. Clara, F.G.; Antonio, F.G.; Manuel, F.V.; Juan, F.; Teresa, G.O.; María, F.G. Physical and mechanical properties of particleboard made from palm tree prunings. Forests 2018, 9, 755. [CrossRef]

18. Tran, L.Q.; Minh, T.N.; Fuentes, C.A.; Chi, T.T.; Vuure, A.W.; Verpoest, I. Investigation of microstructure and tensile properties of porous natural coir fibre for use in composite materials. Ind. Crops Prod. 2015, 65, 437-445. [CrossRef]

19. Shinoj, S.; Visvanathan, R.; Panigrahi, S.; Kochubabua, M. Oil palm fiber (OPF) and its composites: A review. Ind. Crops Prod. 2011, 33, 7-22. [CrossRef]

20. Li, J.; Li, K.; Zhang, T.; Wang, S.; Jiang, Y.; Bao, Y.; Tie, M. Development of activated carbon from windmill palm sheath fiber by, K.O.H activation. Fibers Polym. 2016, 17, 880-887. [CrossRef]

21. Oushabi, A.; Sair, S.; Abboud, Y.; Tanane, O. Natural thermal-insulation materials composed of renewable resources: Characterization of local date palm fibers (LDPF). J. Mater. Environ. Sci. 2015, 6, 3395-3402.

22. Zhang, T.; Guo, M.; Cheng, L.; Li, X. Investigations on the structure and properties of palm leaf sheath fiber. Cellulose 2015, 22, 1039-1051. [CrossRef]

23. Chen, C.; Chen, G.; Sun, G. Windmill Palm Fiber/Polyvinyl Alcohol Nonwoven Fibrous Polymeric Materials. J. Eng. Fibers Fabr. 2016, 11, 4. [CrossRef]

24. Chieng, B.; Lee, S.; Ibrahim, N.; Yoon, T.; Yuet, L. Isolation and characterization of cellulose nanocrystals from oil palm mesocarp fiber. Polymers 2017, 9, 355. [CrossRef] [PubMed]

25. Caramyshev, A.V.; Firsova, Y.N.; Slastya, E.A.; Tagaev, A.; Potapenko, N.; Lobakova, E.; Pletjushkina, O.; Sakharov, I. Purification and characterization of windmill palm tree (Trachycarpus fortunei) peroxidase. J. Agric. Food Chem. 2006, 54, 9888-9894. [CrossRef] [PubMed]

26. Yan, Y.; Wang, H.; Fang, L.; Tian, G.; Lin, J. Bamboo fibers for composite applications: A mechanical and morphological investigation. J. Mater. Sci. 2014, 49, 2559-2566. [CrossRef]

27. Khalil, H.P.; Alwani, M.S.; Ridzuan, R.; Kamarudin, H.; Khairul, A. Chemical composition, morphological characteristics, and cell wall structure of malaysian oil palm fibers. J. Macromol. Sci. Part D 2008, 47, $273-280$. [CrossRef]

28. Zhai, S.; Imai, T.; Horikawa, Y. Anatomical and mechanical characteristics of leaf-sheath fibrovascular bundles in palms. Iawa J. 2013, 34, 285-300. [CrossRef]

29. Kanzawa, E.; Aoyagi, S.; Nakano, T. Vascular bundle shape in cross-section and relaxation properties of Moso bamboo (Phyllostachys pubescens). Mater. Sci. Eng. C 2011, 31, 1050-1054. [CrossRef]

30. Thomas, R. Palm stem anatomy and computer-aided identification: The Coryphoideae (Arecaceae). Am. J. Bot. 2013, 100, 289-313. [CrossRef]

31. Zhang, X.; Li, J.; Yu, Z.; Yu, Y.; Wang, H. Compressive failure mechanism and buckling analysis of the graded hierarchical bamboo structure. J. Mater. Sci. 2017, 52, 6999-7007. [CrossRef]

32. Chen, C.J. Morphology Research of Windmill Palm (Trachycarpus fortunei) Material. Kemija U Industriji. 2015, 64, 467-472. [CrossRef]

33. Lien, N.T.L.; Kolehmainen, H.; Hiltunen, E.; Hiltunen, E.; Nazhad, M. The impact of chemical composition of pulp fiber cell wall on paper recycling potential of fibers. In Improvement of Forest Resources for Recyclable Forest Products; Springer: Tokyo, Japan, 2004. [CrossRef]

34. Zimmermann, T.; Thommen, V.; Reimann, P.; Hugc, H.J. Ultrastructural appearance of embedded and polished wood cell walls as revealed by atomic force microscopy. J. Struct. Biol. 2013, 156, 363-369. [CrossRef]

35. Yu, H.; Liu, R.; Shen, D.; Wu, Z.; Huang, Y. Arrangement of cellulose microfibrils in the wheat straw cell wall. Carbohydr. Polym. 2008, 72, 122-127. [CrossRef]

36. Gindl, W.; Gupta, H.S.; Grünwald, C. Lignification of spruce tracheid secondary cell walls related to longitudinal hardness and modulus of elasticity using nano-indentation. Can. J. Bot. 2002, 80, 1029-1033. [CrossRef]

37. Wu, Y.; Wang, S.; Zhou, D.; Xing, C.; Zhang, Y. Use of nanoindentation and silviscan to determine the mechanical properties of 10 hardwood species. Wood Fiber Sci. 2009, 41, 64-73. [CrossRef] 
38. Yu, Y.; Fei, B.; Zhang, B.; Yu, X. Cell-wall mechanical properties of bamboo investigated by in-situ imaging nanoindentation. Wood Fiber Sci. 2007, 39, 527-535. [CrossRef]

39. Wu, Y.; Wang, S.; Zhou, D.; Xing, C.; Zhang, Y.; Cai, Z. Evaluation of elastic modulus and hardness of crop stalks cell walls by nano-indentation. Bioresour. Technol. 2010, 101, 2867-2871. [CrossRef] 